\title{
Conflicts of preferences and domestic constraints: understanding reform failure in liberal state-building and democracy promotion
}

\author{
Lisa Groß and Sonja Grimm \\ Department of Politics and Public Administration, University of Konstanz, Konstanz, Germany
}

\begin{abstract}
This paper challenges the common explanations that failures of external state-building and democracy promotion are the result of a lack of domestic capacity or a lack of domestic willingness against an externally set liberal agenda of state-building and democratisation. Studying political decision-making on a microlevel, we argue that both explanations fail to capture the multifaceted motivations and interests of domestic actors that go beyond mere 'resistance' against externally induced liberal reforms. Rather, criticism of reforms might be rooted in ideas of social justice and claims to socio-economic security. Furthermore, these explanations tend to overlook the need for domestic elites to bargain with various domestic stakeholders. A case study of Croatian public administration reform illustrates that failure of externally promoted reforms remain an option when significant international resources are available for liberal state-building and the target of reform is a relatively mature bureaucracy.
\end{abstract}

\section{KEYWORDS}

Democratisation; democracy promotion; state-building; local resistance; Croatia; EU; public administration reform

\section{Introduction}

Why do externally induced reforms often fail in transitioning regimes? Common explanations shared by the state-building and the democracy promotion literature are to point at a lack of capacity and a lack of willingness to implement the liberal state-building and democratisation agenda. We challenge these common explanations by taking a closer look at the diverging preferences and motivations among external and domestic actors as well as the domestic constraints reform makers are confronted with during the political processes of state-building. Studying transitioning states on a micro-level, we argue that explaining failure or challenges of liberal-democratic reforms as consequence of a lack of capacity or a lack of willingness obfuscates the multi-faceted motivations, interests and concerns of domestic actors. Furthermore, by ignoring the complexity of political processes of state-building and democratisation, the challenges of coordinating reforms with various domestic stakeholders are often overlooked. Our study shows that the interpretation of domestic behaviour as 'lack of capacity and/or willingness' might be seriously challenged if taking into account (a) domestic motivations for supporting or rejecting 
external reform proposals and (b) the need for domestic elites to bargain with third stakeholders. Domestic actors might not be completely incapable or unwilling to comply with liberal-democratic ideas, but are also compelled to oppose external actors' demands due to domestic constraints.

With the micro-level study of public administration reform (PAR) in Croatia, this contribution shows that - even in a case of reform failure - lack of capacity and lack of willingness cannot adequately describe domestic behaviour in the reform process. Instead, first, we explore that the strategies used by domestic actors to negotiate with external actors over the course of reform were not intended as acts of resistance against the liberal core goals of the reform. Second, we set out to challenge the practice of scholars to declare domestic unwillingness to comply with external reform demands as an expression of 'undemocratic' or 'illiberal' attitudes. Criticism of reform might be otherwise motivated, for example, by concerns about the socio-economic security of those affected by reforms. With 'socio-economic security' we refer to a concept used by the International Labour Organisation (ILO, 2004) describing several dimensions of work-related security among which income security and security of voice representation are the most essential. A closer look at the domestic actors' motivations shows that they might have legitimate reasons to oppose change due to negative side effects of externally induced reform proposals; a fact that is hardly acknowledged by external actors. Third, we argue that domestic governments must find compromises between external reform demands, the preferences of third-party stakeholders and their own strategic interests. Fourth, we demonstrate that international actors refrain from securing voice representation and are reluctant to include third-party stakeholders as they are perceived as potential obstacle to reform (Jarstadt, 2008).

At the same time, we do not claim that all state-building and democracy promotion failures could be explained with domestic motivations other than illiberalism, or with the difficulties of finding compromises with domestic third-party stakeholders. Unwillingness respectively resistance against liberal-democratic values certainly exists in transitioning states subjected to international state-building and democracy promotion, and the case of one specific reform initiative certainly does not allow generalising to the entire universe of state-building experiments. Even so, our findings add relevant dimensions to the debate and allow for alternative routes of explaining externally induced reform failure. The aim of this article is thus to engage more seriously with domestic motivations for critical attitudes about externally promoted reforms, for the institutional constraints of domestic elites and for the social struggles fought in transitioning states.

This paper proceeds as follows: in Section 2, we discuss two common explanations of reform failure and propose a third explanation of reform failure in liberal state-building. In Section 3, we introduce the reader into the reform of the Civil Servants Salary Act (CSSA) in Croatia, the most hotly contested of all PARs, that empirically illustrates our argument. In Section 4, we provide an analysis of narratives of external and domestic stakeholders involved in the reform process. We demonstrate how external and domestic actors differ in their interpretation of domestic motives for resisting reforms and explore substantial domestic constraints overseen by standard explanations of reform failure in liberal state-building. Section 5 concludes. 


\section{Explaining reform failure of state-building and democracy promotion}

Liberal state-building or the promotion of democracy has been on the agenda of international organisations since the early 1990s. Development agencies support transitions to democracy in developing countries (Burnell, 2000), peacebuilding organisations promote liberal democracy in post-war states (Paris, 2004) and the European Union (EU) has made the respect for principles of democracy, rule of law, human rights and market economy a condition for EU membership (European Council, 1993). International actors initiate a series of reforms to re-organise state institutions according to liberal-democratic ideals (Paris, 1997; Wolff \& Wurm, 2011). To build liberal-democratic states, international organisations have developed a wide range of techniques: monitoring elections, strengthen human rights and rule of law, reforming governmental institutions, promoting political participation and free media (Burnell, 2000; Kumar \& Zeeuw, 2006). Programmes that promote transparency, accountability and participation increasingly include components to strengthen the public service and to master PAR (Hilman, 2013).

Building responsive, accountable and legitimate state institutions has become a core goal of international efforts to support state-building and democratisation; and PAR therein constitutes an integral part (Brinkerhoff, 2010; Chandler, 2010). One justification has been an emerging consensus that weak and illegitimate governing institutions are a central cause for stumbling democratisation processes (Džihić \& Segert, 2012; Chandler, 2010, among others).

PAR, as promoted by international actors, follows the model of liberal democracy (Pal \& Ireland, 2009): It seeks to re-organise administrative state bodies based on values of democracy and fiscal responsibility (SIGMA, 2008). This means to reduce the arbitrary use of state power and to implement the principles of accountability, transparency, participation and competition in bureaucracies as well as a system of checks and balances to ensure the rightful application of constitutional powers (Burnell, 2000; European Commission, 2011, p. 8). At the same time, international financial institutions such as the International Monetary Fund (IMF) promote fiscal responsibility - another word for costreduction. Especially in post-socialist countries with huge state administrations, PAR implies the reduction of the state apparatus, entailing cuts in administrative posts and wages (IMF, 2012). Amongst the external actors supporting PAR are the World Bank, the Organization for Economic Cooperation and Development (OECD), the United Nations Development Program (UNDP), as well as various multi- and bilateral donor agencies such as the US aid agency USAID or its British equivalent, the Department for International Development (DFID) (Pal \& Ireland, 2009). In the Western Balkans, the EU plays a key role because it linked its demands for democracy, and human rights to the perspective of eventual EU membership (Grimm \& Mathis, 2015).

It is widely acknowledged by now that these comprehensive attempts to support transitions to democracy from the outside have led to only 'mixed results' or complete failure. Noutcheva (2009) speaks of partial take-over or fake compliance, when discussing the impact of external democracy promotion. It seems that few democratising states managed successfully the transition to full democratic statehood even with extensive international support (Zürcher, 2011). Researchers are thus cautious with regard to the effect of international financial assistance or capacity building programmes in developing countries (Finkel, Pérez-Liñán, \& Seligson, 2007; Knack, 2004). None of the inquiries 
presume that democracy aid has been fully successful (Burnell, 2007; Carothers, 2002; Finkel et al., 2007). In the context of EU accession, most studies find that the EU's power to influence patterns of democratisation in the candidate countries has been impressive, but limited (Sedelmeier, 2011, p. 18). Particularly in the Western Balkans, the success of EU conditionality is not as straightforward as it was in the Central and Eastern European countries (Freyburg \& Richter, 2010; Richter, 2012; Schimmelfennig, 2008; but see also Pawelec \& Grimm, 2014).

Scholars and practitioners feature several explanations for reform failure of liberal statebuilding and international democracy promotion, of which the lack of capacity and the lack of willingness figure as the most prominent (Börzel, 2010, p. 3). Both lines of argument are presented briefly below.

\subsection{Lack of capacity}

The lack of capacity argument points to the lack of financial or human capacity on the domestic side to implement reforms (Doyle \& Sambanis, 2000; Feeny \& McGillivray, 2009; Hameiri, 2009, p. 56). The lack of financial capacity, so one argument, makes it difficult for domestic actors to implement the reform correctly because of insufficient number of staff, equipment or infrastructure. Such lack of resources leads to 'imperfect' implementation of the reform, as governments and bureaucracies of the target state have to set priorities with the scarce resources available. According to this line of thinking, increased international investments could help to level out insufficient domestic financial capacities. Financial assistance is therefore a popular instrument of international actors to support states on their way to democracy (Burnell, 2000, pp. 4-5; Grimm \& Mathis, 2015). In the frame of accession conditionality, the EU offers a large package of financial assistance to potential EU candidate countries (Grimm \& Mathis, 2015).

Also the lack of human capacity complicates reform success, according to some authors in the field of liberal state-building (Caplan, 2004, p. 230; Chesterman, 2007, p. 16) and democracy promotion (Börzel \& Risse, 2004; Burnell, 2000; Carothers, 1999). In this perspective, the problem is that individuals in the government or the state administration are not familiar with the new legal framework, do not yet understand the benefits of an externally induced reform, or do not have the technical skills to implement it correctly. Such lack of human capacity leads to 'imperfect' reform implementation. Following this line of argument, international 'teaching' activities are thought to improve the reform process, as they are geared towards empowering local actors to fulfil the tasks correctly. This is the reason why capacity building and dialogue have become widely used as democracy promotion instruments (Börzel \& Risse, 2004, p. 21). A great bulk of democracy promotion programmes aim to transmit political expertise through capacity building workshops, trainings and expert consultancy (Burnell, 2000, pp. 4-5; Kumar \& Zeeuw, 2006). International actors have sought to establish local civil services or train local civil servants to develop professional, accountable and inclusive public administrations. Also Croatia's public administration has received international assistance in form of capacity building and expert consultancy that aimed to professionalise those responsible to implement administrative reforms (Groß \& Grimm, 2014).

However, the case of Croatia's PAR challenges these explanatory approaches. PAR received considerable financial assistance from the EU and other donors to level out the 
lack of local financial capacity. Civil servants also received manifold expert advice and capacity building trainings from the EU, World Bank, SIGMA and various other donor agencies in several areas of PAR. Yet, experts on the region continue to criticise the Croatian government for its slow progress in the implementation of reforms and in the fight against corruption (European Commission, 2010, 2011; Zakošek, 2008).

\subsection{Lack of willingness}

The lack of willingness argument emphasises domestic elites resistance to an external reform agenda, possibly because local elites show an undemocratic or illiberal attitude. They might also benefit more from the status quo than they would from implementing an externally pushed reform package, and which might be overcome by increased international pressure. Explaining setbacks of liberal state-building and democratisation with lack of willingness or, in other words, the 'resistance' of domestic actors, is a widespread practice among practitioners and scholars alike (Menkhaus, 2003; Pearlman, 2008; Stedman, 1997). Critical peacebuilding scholars have recently taken up the term 'resistance' to make sense of unsuccessful international attempts in re-structuring states based on liberal-democratic principles (Mac Ginty, 2010; Richmond, 2010, 2011; Richmond \& Mitchell, 2011). Various modes of domestic behaviour such as contestation, rejection, reshaping, co-option or modification are interpreted as acts of 'resistance' (Richmond, 2010, p. 685) at things as diverse as liberal values, pluralism, rights-based approaches, universality, individualism, and free markets (Richmond, 2010, p. 669; Richmond \& Mitchell, 2011 , p. 326). Researchers suppose that the massive arrival of staff involved in international governance creates a social gap between the international and the local "worlds"' (Lemay-Hébert, 2011, p. 1824), which in turn might fuel narratives of local resistance.

In the post-conflict democratisation literature, lack of domestic willingness is attributed to presumably un-democratic political elites who oppose the opening of the political or economic sphere in an attempt to maintain their tight grip on state power (Carothers, 1997, p. 122; Stedman, 1997). Following Carothers (2004), a lack of willingness is expressed in domestic resistance against external reform initiatives that would threaten the power, worldview or interests of the currently governing elites. He interprets stalled democratisation as 'deeply embedded resistance to any change' (Carothers, 2004, p. 137), referring to autocratic leaders that continue to cling to their power and therefore resit external democratisation demands (Carothers, 1997, p. 122). Similarly, the literature on EU compliance explicates the failure to fully adopt EU norms and rules with 'resistance' on the domestic side that is due to strategic considerations of the political elite, who have to weigh adoption costs against benefits of compliance (Schimmelfennig \& Sedelmeier, 2004). Domestic actors, so the conclusion, resist democratic state-building because they prefer less democratic solutions which would keep them in their power position. Authors more critical of international attempts to establish democratic regimes from the outside interpret such lack of willingness as the refusal to accept the authority of international organisations that are dominated by the West, and their ideals of a liberal-democratic state that may not resonate with local needs (Richmond, 2010, pp. 685-686).

While we share the unease with many of the international practices to build liberal states and promote democracy, we challenge the interpretation of domestic behaviour 
as 'lack of willingness' or 'resistance against liberal democracy' as in this explanation, the wide array of domestic motivations and the complex processes needed to manage, modify or even reject external demands are systematically underestimated as relevant for explaining domestic reform success or failure.

\subsection{Conflicts of preferences and domestic constraints}

In fact, a liberal state-building reform can fail even though the state in question is - compared to many other states in the developing world - well institutionalised and counts on a well-educated workforce, and has received considerable international support to minimise the lack of financial and human capacity. Likewise, observing the attitude of domestic actors towards external demands might not allow the conclusion that governments and state officials have a 'lack of willingness' and necessarily oppose the fundamental ideas underlying an external reform initiative.

Based on our case study of PAR in Croatia and with a hint to existing, but not yet well reflected literature (Dietrich, 2014; Grimm \& Leininger, 2012; Hughes, 2013; Molenaers, 2012), we propose a third explanation for reform failure in liberal state-building and democracy promotion. Our focus is on potential conflicts of preferences that arise during policy-making between the actors involved. This might either lead to a compromise - and be possible judged as 'mixed result' due to its divergence from the external actors' ideal point; or the delay in or complete lack of reform adoption - and possibly be judged as 'reform failure'. Such a view acknowledges the fact that policy-making in democratising countries under external influence is the result of negotiations between all stakeholders external actors, domestic governments and third parties at different stages of a policycycle including agenda-setting, policy-formulation, policy-adoption, policy-implementation and evaluation. In liberal state-building and democracy promotion, external actors de facto participate in all stages of policy-making, with policy-adoption in domestic parliaments being the only stage in which external actors are formally excluded. The domestic government is thus involved in a two-level game (Putnam, 1988), having to negotiate with international actors and domestic third parties at the same time. Thus, these interactions can be observed throughout the entire process, making the policy-cycle a useful tool to separate the different phases of interaction between democracy promoters, national actors and third parties (for further explanation, see Groß \& Grimm, 2014).

Newer literature on aid effectiveness hints to the fact that multilateral and bilateral donors differ in their preferences of aid delivery politics (Dietrich, 2014; Molenaers, 2012). Moving this idea further, we suggest also considering the conflicts of preferences between external and domestic actors and within domestic actors setting for explaining reform failure. Such conflicts can emerge on all stages of the policy-cycle. Following Grimm and Leininger (2012), we observe a conflict of preferences among external and domestic actors that impedes the reform process. We argue that the domestic preferences of what kind of reform should be achieved and how the reform should be achieved differ from those of the external actors. Instead of classifying such disagreements and the respective domestic agency as 'resistance', we propose to investigate more precisely the content of external and domestic preferences and motivations to better understand domestic responses to external reform demands. 
Following the literature on preference formation (Streich \& Levy, 2007; Walter, 2008), we assume that domestic actors are consistent in their preference structure and prefer the policy outcome to which they are least vulnerable. They place greater weight on shortterm trade-offs than on possible long-term trade-offs, and they prefer gains over losses (Streich \& Levy, 2007, p. 1999; Walter, 2008, p. 412). Uncertainty about the (intended and unintended) effects of reform policies reinforces this mechanism. As domestic actors prefer short-term gains, and cannot completely foresee the consequences of reform that might even be negative for their individual life, the perceived vulnerability against externally demanded reforms increases.

We illustrate this point with the example of PAR. PAR seeks to make public services more efficient and less costly and potential negative consequences are for example a reduction of wages or a loss of jobs. When domestic actors anticipate such negative consequences of a suggested reform package, they presumably start to change the reform proposal in order to secure gains and avoid losses - a rational behaviour that external actors, however, might misperceive as 'resistance'. Subsequently, the negotiations between external and domestic actors over the reform do not come to a solution that satisfies both sides, and the reform fails. We expect that if external actors would be more sensitive to the preferences and needs of domestic actors, the risk of reform failure could be reduced.

Additionally, the effects of domestic constraints need to be taken into consideration to explain reform failure. With domestic constraints, we mean the diverging interests of domestic political parties, political opposition and other domestic stakeholders affected by a reform process who can become veto players in policy-making. Domestic governments need to moderate and negotiate with such actors. External actors might tend to misperceive domestic negotiations as resistance and unnecessary prolongation of the reform process. However, we propose to reinterpret such negotiations as typical domestic constraints that all (consolidated and developing) democracies are confronted with in policy-making (for a similar argument see Hughes \& Hutchinson, 2012, p. 18). These constraints impede reform processes in transitioning countries the more, the more domestic actors gain democratic policy-making capacity. In other words: while domestic actors in transiting countries get empowered through state-building and democracy promotion, they get increasingly aware of the necessity to negotiate with domestic stakeholders the shape and outcomes of political reform. They do so to secure legitimacy and approval of their reform policies. Table 1 summarises the three explanations for reform failure in liberal state-building and democracy promotion.

Table 1. Explaining reform failure in liberal state-building and democracy promotion.

\begin{tabular}{ll}
\hline Explanation & Rationale \\
\hline $\begin{array}{l}\text { Lack of financial and human } \\
\text { capacity }\end{array}$ & $\begin{array}{c}\text { Reform failure due to insufficient number of staff, equipment, infrastructure; } \\
\text { officials not familiar with rules and processes of good public governance and } \\
\text { administration }\end{array}$ \\
$\begin{array}{l}\text { Lack of willingness/domestic } \\
\text { 'resistance' }\end{array}$ & $\begin{array}{c}\text { Reform failure due to domestic resistance against any form of change due to fear of } \\
\text { Conflicts of preferences and } \\
\text { domestic constraints }\end{array}$ \\
& $\begin{array}{l}\text { Reform failure due to diverging priorities among external and domestic actors over } \\
\text { type, scope and procedures of reform; need on domestic side to negotiate with } \\
\text { domestic stakeholders }\end{array}$ \\
\hline
\end{tabular}

Source: Authors' compilation. 


\section{Croatia's PAR as case study}

To illustrate our argument, we analyse the reform process of Croatia's PAR, particularly the CSSA, and examine underlying preferences of external and domestic actors for reform and their interpretations of the outcome on the basis of these actors' individual narratives. Croatia serves in our study as a textbook case for externally supervised state-building and international democracy promotion with the external actors' aim to build up a functioning market-oriented liberal-democratic state ready for EU membership, and a domestic counterpart that remains divided between reformers and status-quo seekers. Croatia was part of the universe of transitioning countries in the East and Southeast of Europe that has received since 1990 substantial international financial support not only for socio-economic development, but also for state-building and democratisation. ${ }^{1}$ This aid was complemented by considerable political incentives to reform due to the perspective of EU membership. In general, such aid supply was effective in overcoming the lack of financial and human capacity Croatia was confronted with after the violent dissolution of the Socialist Federal Republic of Yugoslavia. Furthermore, Croatia's elites showed tremendous political willingness to comply with EU membership conditionality. Consequently, Croatia was awarded EU accession at 1 July 2013.

Although the conditions for liberal state-building in Croatia have hence been advantageous, PAR, and in particular the reform of the CSSA turned out to be more challenging than originally expected. Negotiations for a reform of the CSSA already started in 2003, but until 2012, the parliament did not pass a legislation that complies with external actors' reform demands. Instead of a unified wage system valid for all levels of the federal state, the parliament opted for individual solutions at nation, sub-national and local levels (Republic of Croatia, 2012, p. 66). We will demonstrate in the remainder of this contribution in greater detail that explanations preferred by external actors such as a lack of capacity and a lack of willingness do not fully capture the process and the outcomes of reform, but conflicts of preferences between external and domestic actors as well as domestic constraints on the Croatian side need as well to be taken into account.

As data source for our analysis, we use 30 expert interviews (held between August and November 2011). Domestic interview partners (marked with D) were involved in preparing or implementing specific reforms within the Ministry of Administration, negotiating PAR as part of the Chief Negotiators' Office, managing EU financial assistance to PAR or participating as civil society stakeholders. The external actors interviewed (marked with E) included members of the EU delegation, members of EU financial assistance projects and representatives of the other donors active in the field. These interview partners where asked for another study on PAR (see Groß \& Grimm, 2014) about how externals and the Croatian government negotiated the PAR reform package and its implementation. During these talks, interviewees form both groups shared their personal thoughts on how they perceive the progress of the reform process. Interviewees were not proactively asked, for example, whether and why the reform 'failed'. Without being forced through such a potentially pejorative interview question, interviewees started to blame the other side for 'unwillingness' (externals judging upon locals) or 'ignorance of local circumstances' (locals judging upon externals). The - rather unintended - interview turnout of mutual and self-evaluation allows us analysing how both sides assess the reform process' progress and how they explain its outcomes. The information taken from the interviews are cross-checked and 
complemented by document analysis of annual EU Progress Reports, Pre-Accession Economic Recovery Programmes and project evaluations as well as secondary scholarly and grey literature. Thereby, we can clearly reveal the diverging preferences of both sides and the contrasting assessments of the other involved in the reform process.

\subsection{External and domestic preferences for the CSSA in 2003}

With the CSSA external actors seek to determine the payment system for all civil servants among others state civil servants and staff of education, public health, police or emergency services (SIGMA, 2008). In 2003, the calculation of public salaries was (and still is) non-transparent, fragmented and not performance based. The salary of civil servants is regulated by several different laws for the various groups of employees and public service organisations in health care, education and municipal services. In addition, a number of special laws, decrees and collective agreements have led to significant differences between the wages of these groups (SIGMA, 2007, p. 17).

External actors including the EU and the IMF sought to unify the wage system and to align it with the principles of equal pay for equal work, performance-based payments, introduce a more competitive salary system for top-level administrative positions and fiscal responsibility (European Commission, 2010, p. 7). Whereas the EU was primarily concerned with improvements in the professionalisation and service orientation of the civil service, the IMF (and to a lesser extent the World Bank) stressed the importance of cutting public expenditures and focusing on reduction in public-sector employment, wage moderation or wage freeze (IMF, 2012). The OECD-financed administration specialists SIGMA, and British, Danish and Swedish bilateral assistance seek to build capacity of the administrative leadership and staff.

Following IMF recommendations, in 2003, the Croatian government committed to reduce public-sector spending from $11 \%$ to $10 \%$ of its annual GDP by rationalising the internal organisational structure and decreasing the number of civil servants. However, a very well-institutionalised tripartite system - the so-called 'social partnership' - required the government to negotiate with the trade unions of public and civil servants on salaries (Interview D1, Independent Researcher) through comprehensive multi-annual collective agreements. In the negotiations over the CSSA, the Ministry of Administration had to coordinate discussions between the Ministry of Finance, all Ministries in charge, and the trade unions for civil and public servants.

The Ministry of Finance, backed by international organisations, generally opposed solutions that would raise public spending (SIGMA, 2008, p. 13). Some trade unions, to the contrary, opposed potential decreases in the wages of their members or in the number of positions.

\subsection{The reform process (2003-2012)}

When discussions over the reform of the CSSA started, the Croatian government agreed with external actors on the need for reform. Yet it had internal difficulties in finding a compromise with all relevant stakeholders from the various ministries and trade unions of the social partnership. External actors in turn tried to speed up the reform process offering international consultants and financial assistance. Croatian decision-makers established 
a working group with all stakeholders of the social partnership to discuss a new Salary Act. International consultants analysed the salary and remuneration system in Croatia, made policy recommendations, and proposed laws to be discussed in the working group. Already by then, reconciling all interests proved a challenge. Every time when parliamentary discussion of the law neared, the Croatian government postponed the decision of a new salary act - in 2005, and 2007/2008. The first time, a World Bank consultant had prepared a draft law of the CSSA based on three different salary systems. The government, which had previously approved this solution, rejected the proposal, voicing preference for a unified salary system and the discussion in parliament had to be postponed (Interview E02, Bilateral Donor). In 2007, the government - again with the help of international consultants - developed a new draft law of the CSSA based on a unified salary system. This time, trade unions did not agree to the proposal and the government - unwilling to incorporate the trade unions' demands because of the uncertain fiscal impact - again postponed the discussion parliament because it feared protests led by trade unions (Republic of Croatia, 2007, p. 66).

After these two unsuccessful attempts to bring the reform forward, the EU and other external actors reverted to more coercive means to accelerate the reform process. The donors issued a written recommendation to the government demanding more rapid reforms (Interview E05, EU Delegation). Yet, the government and trade unions were still unable to reach an agreement. As a response, external actors decided to use conditionality to push the process: the adoption of the Salary Act was made a pre-condition for a financial grant to the Ministry of Administration (Interview E05, EU Delegation). Yet, the Croatian government refused to push through the reform without trade unions' consent. In the end, the EU dropped this pre-condition and provided financial assistance despite the lack of compliance.

In this time, the government and the working group continued to work on a draft proposal, which then was submitted to the Croatian parliament for the first time in January 2009. Yet, the parliament postponed the decision because there were doubts about the laws' financial sustainability. Severe protests and strikes by trade unions followed because the unions feared further proposals to be less favourable to their demands. In autumn 2009, the EU started another attempt to increase reform pressure. It made use of EU accession conditionality and introduced the adoption of the Salary Act as a benchmark of Chapter 22 of the accession negotiations. Again, the Croatian government did not succumb to this demand. It insisted that an agreement with the trade unions must first be reached, or the country would again face strikes and social unrest. In the end, the EU and the Croatian government agreed to a compromise, and the EU dropped its demand for a new Salary Act.

In the spring of 2011, another round of negotiations started, but again no agreement could be reached. Further meetings of the working group were delayed until after the elections in November 2011. After the elections, different agreements for the national, sub-national and local level public servants were proposed to be negotiated. In 2012, the parliament finally opted for individual solutions at national, sub-national and local levels (Republic of Croatia, 2012, p. 66), instead of a unified salary system that was originally demanded by the external actors. In the eyes of the externals, the original reform package failed; in the eyes of domestic actors, the reform package was modified and adapted to local purposes. 


\subsection{Analysis of the reform outcomes}

The negotiations over the CSSA reform thus illustrate that reform failure and 'mixed results' do not need to be the outcome of financial or human incapacity, or lack of domestic commitment of reform. Rather, the government, particularly the Ministry of Administration as the coordinator of reform, failed to reach a viable domestic compromise with third-party stakeholders and to reconcile diverging external and domestic preferences in order to reach an agreement.

In the following, we show how the different parties to the conflict perceived the reform process. The interview data exemplifies that international actors tend to portray reform failure as a result of 'lack of willingness' and 'lack of capacity', although the motivations given by domestic actors do not support such a conclusion.

\section{External and domestic interpretations of process failures and outcomes}

External and domestic actors have widely divergent views when asked about an explanation for the slow progress and final outcome in the reform of the CSSA.

\subsection{The external actors' view on reform failure}

When representatives of the international community are asked for the reasons why the CSSA reform has failed, a rather shallow picture of the Croatian actors' commitment to democracy emerges. The external actors interpret Croatian reluctance to adopt the Salary Act as a sign of incapacity or 'resistance' to reform goals raising suspicion that 'the government was not eager to move forward' (Interview E15, World Bank). One common interpretation is the incapacity of domestic actors to fully implement the reform. Those responsible for managing the reform process are describe as 'bad managers' (Interview E29, Embassy) that are appointed 'because they are member of a party' (Interview E29, Embassy). One external actor complains:

It's a very high degree of high ranking officials in Croatia that know zero about the EU, have no foreign language proficiency, and have absolutely no interest in creating a system that first of all means that people working for them learn more and get more qualifications than them, and second, which we were aiming at, resorted in increased requirements in knowledge and competences for themselves. (Interview E00, Bilateral Donor)

Capacity problems are often located at the higher ranking level, where external actors claim they 'haven't seen any transformation in this sphere from the previous Yugoslav socialist self-management approach.' (Interview E00, Bilateral Donor):

It is also clear to them that at their stage in life, it is too late to start all over. They can't learn languages fast enough or change their basic legal understanding. So they are creating a temporary legal vacuum where everything around them changes but the way 'we do things don't change, because that's the only way WE can survive'.

'Lack of willingness' or 'resistance' is also often used as explanation for slow reform progress, as external actors assume that 'there was simply no appetite for it' (Interview E15, World Bank). This was usually combined with complaints about the government's low 
level of commitment to advancing the reform: (Interviews E00, Bilateral Donor; E03, British Council; E15, World Bank; E29, Embassy)

There were no reactions. That is simply it. [ ... ] The laws were prepared in 2007, and they had long discussions with unions and nothing happened. [ ... ] Today is 2011, and nothing. (Interview E15, World Bank)

The critical attitude of trade unions is similarly explained with domestic 'lack of willingness': the trade unions are regarded as equally unwilling to reform, and are portrayed as opponents of reform initiatives in general. Trade unions are regarded as old-fashioned and status-quo-oriented and suspected of sympathising with the old Yugoslav socialist system instead of democracy (Interview E29, Embassy). Little differentiation is made between the various positions of different trade unions; all are perceived as equally 'unwilling':

Well, they [the trade unions] are opposing every reform in general. Whatever you propose, you know, there is a very high insistence on protecting the status quo, but when it comes to criticizing the current situation, they will also be among the first ones that say, 'We disagree with the current system.' (Interview E15, World Bank)

This portrayal of domestic actors, government and trade unions, as generally 'unwilling to reform' has an interesting connotation. Because any reform induced by international actors in post-conflict countries is closely connected to the liberal democratisation agenda in its rhetoric, being 'unwilling to reform' is almost always equated with being 'un-democratic' or 'illiberal'. One international employee was particularly explicit in his linking of what he perceived as 'resistance' to reform with un-democratic intentions:

There is a steady production of small grey persons going out who have been effectively brainwashed with what is effectively socialist legal education. [...] What we tried to implement into this act is that the citizen is no longer the object for your authority. [ ... ] But the approach of the Croatian administration is that every citizen is a potential criminal. (Interview E00, Bilateral Donor)

External actors are aware of the fact that specific aspects of the reform could be difficult for trade unions to accept - such as the rationalisation of personnel - but it is not accepted as legitimate reason for 'resistance' or 'lack of willingness'. Trade union's criticisms of rationalisation plans are framed as 'some people losing privileges' (Interview EOA, SIGMA) and not as a struggle to retain socio-economic security for their members. Rationalisation is presented as an 'objective need' that trade unions are unwilling or unable to accept and resistant to taking the 'necessary steps for its implementation' (Interview E03, British Council).

The perception of trade unions as resisting the external actors' goal for a new salary system has important consequences for their approach towards these particular stakeholders. Even though there has been a strong, even formal, social contract between the government and a social group (e.g. trade unions), external actors tried to exclude eventual 'spoilers' from the reform process (Interview E03, British Council). The EU concentrated its pressure almost exclusively on the government in an attempt to circumvent this third actor: 'We do recognise that it requires consultations with social partners. I think this was simply used as an excuse for not doing the reforms' (Interview E15, World Bank). The existing social contract between the government and trade 
unions is not regarded as an inherent part of democratic decision-making in which stakeholders are granted the opportunity to participate, but rather as an inefficient policymaking strategy:

At the end, the whole process was so time-consuming, because all the secretary general of all the line ministries and all state administration and unions - it was consensus-building approach - and at the end, I guess, completely diluted the reform impact, because by waiting for everybody to reach the same line of thinking, it drives you ... (Interview E15, World Bank)

As a result of this perception, external actors called for a stronger top-down approach by the government vis-à-vis its social partners. There has even been an observable tendency to try to exclude trade unions from the reform process for as long as possible:

[B]ut, I mean, they [the trade unions] will come up with things, you know, I haven't really felt them very active. I mean, they don't get involved, I mean. People don't tend to involve the trade unions until the very last, because they can always fail complaints. (Interview E03, British Council)

This strategy of exclusion is especially interesting, considering the fact that external actors generally demand 'civil society participation' from governments as an integral part of democratic policy-making. Apparently, this does not hold for social actors that are perceived as 'resistant' to external actors' goals.

\subsection{The government's view on reform failure}

Government representatives have different explanations for the stalled reform process. Interviews with representatives of the government and trade unions demonstrated that both sides seem interested in reform. However, this reform is not regarded as a technical question that requires 'objective solutions', but rather as a social struggle for socio-economic security, which in turn demands sensitive handling. For the government, the social contract with trade unions could be felt in the day-to-day negotiations of the reform process, and the reconciliation of the various interests was represented as a great challenge.

Croatian government officials expressed support for a reform of the CSSA and the introduction of a unified performance-based salary system. The coordinator of negotiations in the Ministry of Administration was certain that ' $\mathrm{t}$ ] he government will try to change the law for civil servants to fulfil the goal of pay according to performance as a motivation for good work' (Interview D27, Ministry of Administration). Another employee of the same ministry also acknowledged the importance of introducing a performance-based salary system because '[s]alary is a big issue, because of [a] weak salary system, most of [the] problems of organisation of ministries and state administration basically rise' (Interview D25, Ministry of Administration).

In the eyes of government representatives, the primary difficulty of the CSSA reform has been to reconcile competing stakeholder interests. On the one hand, the Ministry of Finance, backed by international organisations, has opposed solutions that would increase public spending; on the other hand, some trade unions have opposed a decrease in the wages of their members (Interview D27, Ministry of Administration). Within this constellation, finding a compromise is represented a real challenge. The government has been 
reluctant to use a stronger top-down approach, as demanded by external actors, because it wants to maintain cooperative relations with the trade unions and avoid public protests:

So if we want to correct the imbalance, we should raise the salaries of some civil servants, we cannot cut the salaries of those who are overpaid. Because otherwise we would have people on the streets, probably thousands of people, even though it [the salary system] is not justified. (Interview D27, Ministry of Administration)

The Croatian government also offers a different description of the trade unions, which external actors tended to dismiss as reform unwilling and socialist fashioned. The government perceives trade unions as generally cooperative, acknowledges the diversity of positions held by the various unions, and also expresses understanding for their concerns. In general, the attitude of trade unions is perceived as supportive of the reform:

I think they are cooperative. When it comes to civil service trade unions, they are. Trade unions are quite active and if there are discussions on cut-down they become more socially sensitive: 'Who is going to lose a job, can we try to re-train them for something else?' (Interview D23, Chief EU Negotiators Office of the Croatian Government)

The quote shows that the Croatian government acknowledges the social implications of reforming the CSSA in case of wages and positions would be reduced. Here, the critical attitude of trade unions is interpreted as social sensitivity with regard to the economic implications for union members. In addition, there is an understanding for the difficult position of trade unions vis-à-vis their members, as '[t]hey want to protect interest of their members. And they have to (calculate) that some of their members will not like that ...' '(Interview D07, Department for EU Funds for Institution Building, CODEF). In summary, the government's perception of trade unions is more nuanced than the portrayal by external actors.

\subsection{The trade unions' view on reform failure}

Trade unionists in our interviews have voiced support for the reform process. One trade union representative stresses that '[m]ost of the people are ready to accept new solutions' (Interview D10, Trade Union Higher Education). In interviews, union members acknowledged the value of the external actors' principle reform goals, such as performance based, transparent, equal and fair pay for all civil servants (Interviews D10, Trade Union Higher Education; D11, Trade Union Civil Servants; D18, Trade Union Higher Education). Some trade union representatives even expressed impatience with the reform progress:

Reform? What reform? There is no significant change in the public sector. We are trying for several years to impose some new laws on salaries, but each time they [the government] quit. [...] We are interested in reforms and are proposing our views on the problem of salaries, but we are not able to finish this job. (Interview D10, Trade Union Higher Education)

With regard to the reasons for the lack of progress in the reform process, the trade unions (like the government) point to the difficulty in finding a compromise acceptable to all stakeholders. In addition, the trade unions also raise the difficulty of being accountable to their members and having to justify any agreement to them:

We find solution in discussion, but the final solution is not good enough. Lot's of troubles. We know our members and the situation on the ground. It's a problem. (Interview D10, Trade Union Higher Education) 
The reluctance of the trade unions to agree to the reform proposals is based on very specific aspects of the reform: attempts to reduce wages and the number of positions. It is one of the main missions of trade unions to defend wages and working places of their members. Thus, the main reason for trade unions to reject drafts of the CSSA were drastic reductions in staff and wages because this would endanger the socio-economic security of some of their members (Interviews D10, Trade Union Higher Education; D11, Trade Union Civil Sevants; D18, Trade Union Education; D23, Office of Chief EU Negotiator). However, some members of trade unions are also aware that the reform might require cuts (D11, Trade Union Civil Servants). Trade unions view their resistance to the current reform proposals as part of a social struggle for socio-economic security (Interview D10, Trade Union Higher Education).

We agree with the media and the world of business that the public system is not effective, but it is the ONLY problem of the public system in Croatia. It is not effective, but it is not too great.

[... ] (Interview D10, Trade Union Higher Education)

Apart from these general concerns, trade union members also voice doubts about the proper implementation of a performance-based salary system, such as whether it is possible to conduct an objective evaluation in an environment pervaded by clientelism, and the negative impact such evaluations might have on working relationships (Interview D10, Trade Union Higher Education). The perspective of trade unions on salary reform does not point to a general unwillingness to reform, but reveals concerns about the socio-economic security of their members and worries about the functionality of the reform proposals on the table.

\section{Conclusions}

Not every reform failure of international democracy promotion and liberal state-building is the result of domestic 'lack of capacity' or 'lack of willingness' to implement liberal-democratic reform goals. Taking the administration reform of the CSSA in Croatia as an example, we showed that a closer look at the domestic context of reform reveals alternative explanations for reform failure. Our micro-level approach allowed discovering complex internal reform dynamics and disentangling the different domestic motives for supporting or criticising external reform proposals. Domestic constellations, especially the need of the government to negotiate with trade unions over the reform, played a more important role. We also find that external and domestic actors hold different interpretations about the failure to find an agreement on the reform of the CSSA. External actors tended to portray domestic 'resistance' as a general unwillingness or incapacity for democratic reform in both the government and the trade unions. Socio-economic reasons for resistance on the part of the trade unions were either neglected or dismissed as irrelevant, with the external actors instead emphasising the need for a stronger top-down approach by the government. The domestic interpretation of 'local resistance' was more nuanced. Contrary to the picture presented by externals, the domestic actors were not opposed to the reform in general; rather, they pointed to the difficulty of reconciling the interests of various stakeholders, and to the potential social implications of reforming the salary system. Reforming the salary system was not regarded a technical question, but part of a social struggle that would require sensitive handling by the government to address 
the demands of local stakeholders (e.g. trade unions) that form part of the social partnership.

The empirical footage illustrates that 'unwillingness' exists foremost in the interpretation of external actors. In a transition country, observed domestic behaviours are not necessarily a sign of anti-democratic or anti-modern attitudes; they can instead be based on ideas of social justice and claims to socio-economic rights.

We therefore argue that a more careful identification of domestic preferences and objectives in reform processes as well as a deeper understanding of domestic dynamics in policy-making is required. We concur with the conclusion of Kappler and Richmond $(2011$, p. 273) that there is a need for external actors to 'recognise and respond to unfamiliar local critical [...] agencies and resistance in more positive forms rather than merely downplaying complexities of local processes' (Kappler \& Richmond, 2011, p. 273). In addition, we recommend that scholars should not fall into the trap of unquestioningly accepting external actors' interpretations of what qualifies as 'lack of capacity' or 'lack of willingness'. As our case study shows, external and domestic actors might agree upon general objectives for liberal state-building; however, they might substantially differ in the scope and scale of desired reforms, in the necessary degree of local third-party participation in policy-making, and in the implementation of the reform. At all stages, external actors should begin to take domestic concerns seriously and develop context-sensitive approaches to supporting liberal state-building and democratisation. At times, the socalled 'lack of reform progress' might be a misperception on the part of external actors rather than a real problem for domestic actors.

\section{Note}

1. A detailed assessment of the external actors' activities in the Western Balkans, and in Croatia particular, is beyond the scope of this paper; please see Grimm and Mathis (2015) for an overview.

\section{Acknowledgements}

We would like to thank Claudia von Braunmühl, Michael Daxner, Stefanie Kappler, Ulrich Schneckener, Gerald Schneider, the participants of the panel 'Who Wants Peacebuilding?' at the German Association for Peace and Conflict Studies Annual Conference 2012, the members of the research network 'External Democracy Promotion' and anonymous reviewers for their helpful comments on earlier versions of this manuscript. Special thanks to Claire Bacher for her kind and careful proofreading. Financial support from the Young Scholar Fund at the University of Konstanz is gratefully acknowledged.

\section{Disclosure statement}

No potential conflict of interest was reported by the authors.

\section{Notes on contributors}

Lisa Groß received her PhD at the Department of Politics and Public Administration, University of Konstanz, Konstanz, Germany. 
Dr Sonja Grimm is a Senior Lecturer at the Department of Politics and Public Administration, University of Konstanz, Konstanz, Germany.

\section{References}

Börzel, T. (2010). The transformative power of Europe reloaded. The limits of external Europeanization (KFG Working Paper). Berlin: Freie Universität Berlin.

Börzel, T., \& Risse, T. (2004). One size fits all! EU policies for the promotion of human rights, democracy and the rule of law. Paper Prepared at the Workshop on Democracy Promotion. Stanford: Center for Development, Democracy and the Rule of Law, October 4-5.

Brinkerhoff, D. W. (2010). Developing capacity in fragile states. Public Administration and Development, 30, 66-78.

Burnell, P. (2000). Democracy assistance: The state of the discourse. In P. Burnell (Eds.), Democracy assistance. International co-operation for democratization (pp. 1-33). London: Frank Cass.

Burnell, P. (2007). From evaluating democracy assistance to appraising democracy promotion. Political Studies, 5(2), 414-434.

Caplan, R. (2004). Partner or patron? International civil administration and local capacity building. International Peacekeeping, 11(2), 229-247.

Carothers, T. (1997). Democracy assistance. The question of strategy. Democratization, 4(3), 109-132.

Carothers, T. (1999). Aiding democracy abroad. The learning curve. Washington, DC: Carnegie Endowment for International Peace.

Carothers, T. (2002). The end of the transition paradigm. Journal of Democracy, 13(1), 5-21.

Carothers, T. (2004). Critical mission. Essays on democracy promotion. Washington, DC: Carnegie Endowment for International Peace.

Chandler, D. (2010). International statebuilding: The rise of post-liberal governance. London: Routledge.

Chesterman, S. (2007). Ownership in theory and practice. Transfer of authority in UN statebuilding operations. Journal of Intervention and Statebuilding, 1(1), 3-26.

Dietrich, S. (2014). Donor political economies and the pursuit of aid effectiveness. Paper presented at the EPSA annual conference, Edinburgh, June 19-21.

Doyle, M. W., \& Sambanis, N. (2000). International peacebuilding. A theoretical and quantitative analysis. American Political Science Review, 94(4), 779-801.

Džihić, V., \& Segert, D. (2012). Lessons from "Post-Yugoslav" democratization: Functional problems of stateness and the limits of democracy. East European Politics \& Societies, 26(2), 239-253.

European Commission. (2010). Croatia 2010 progress report. Brussels: European Commission.

European Commission. (2011). Croatia 2011 progress report. Brussels: European Commission.

European Council. (1993). Copenhaguen criteria. Council conclusions. Brussels: European Council.

Feeny, S., \& McGillivray, M. (2009). Aid allocation to fragile states: Absorptive capacity constraints. Journal of International Development, 21(5), 618-632.

Finkel, S. E., Pérez-Liñán, A., \& Seligson, M. A. (2007). The effects of U.S. foreign assistance to democracy building, 1999-2007. World Politics, 59(3), 404-439.

Freyburg, T., \& Richter, S. (2010). Identity matters. The limited impact of EU conditionality in the Western Balkans. Journal of European Public Policy, 17(2), 263-281.

Grimm, S., \& Leininger, J. (2012). Not all good things go together. Conflicting objectives in democracy promotion. Democratization, 19(3), 391-414.

Grimm, S., \& Mathis, O. L. (2015). Stability first, development second, democracy third: The European Union's policy towards post-conflict Western Balkans, 1991-2010. Europa-Asia Studies, 67(6), 916 947.

Groß, L., \& Grimm, S. (2014). The external-domestic interplay in democracy promotion: A case study on public administration reform in Croatia. Democratization, 21(5), 912-936.

Hameiri, S. (2009). Capacity and its fallacies: International state building as state transformation. Millennium: Journal of International Studies, 38(1), 55-81.

Hilman, B. (2013). Public administration reform in post-conflict societies. Lessons from Aceh, Indonesia. Public Administration and Development, 33(1), 1-14. 
Hughes, C. (2013). Friction, good governance and the poor: Cases from Cambodia. International Peacekeeping, 20(2), 144-158.

Hughes, C., \& Hutchinson, J. (2012). Development effectiveness and the politics of commitment. Third World Quarterly, 33(1), 17-36.

ILO. (2004). Economic security for a better world: Programme on socio-economic security. Geneva: ILO Press.

International Monetary Fund. (2012). Croatia-concluding statement of IMF staff visit. Author.

Jarstadt, A. K. (2008). Dilemmas of war-to-democracy transitions. Theories and concepts. In A. K. Jarstadt \& T. D. Sisk (Eds.), From war to democracy. Dilemmas of peacebuilding (pp. 17-36). Cambridge: Cambridge University Press.

Kappler, S., \& Richmond, O. (2011). Peacebuilding and culture in Bosnia and Herzegovina. Resistance or emancipation? Security Dialogue, 42(3), 261-278.

Knack, S. (2004). Does foreign aid promote democracy? International Studies Quarterly, 48(1), $251-$ 266.

Kumar, K., \& Zeeuw, J. (2006). Democracy assistance to post-conflict societies. In J. de Zeeuw \& K. Kumar (Eds.), Promoting democracy in post-conflict societies (pp. 1-24). Boulder: Lynne Rienner.

Lemay-Hébert, N. (2011). The bifurcation of the two worlds: Assessing the gap between internationals and locals in state-building processes. Third World Quarterly, 32(10), 1823-1841.

Mac Ginty, R. (2010). Hybrid peace: The interaction between top-down and bottom-up peace. Security Dialogue, 41(4), 391-412.

Menkhaus, K. (2003). State collapse in Somalia. Second thoughts. Review of African Political Economy, $30(97), 405-422$.

Molenaers, N. (2012). The great divide? Donor perceptions of budget support, eligibility and policy dialogue. Third World Quarterly, 33(5), 791-806.

Noutcheva, G. (2009). Fake, partial and imposed compliance. The limits of the EU's normative power in the Western Balkans. Journal of European Public Policy, 16(7), 1065-1084.

Pal, L. A., \& Ireland, D. (2009). The public sector reform movement: Mapping the global policy network. International Journal of Public Administration, 32(8), 621-657.

Paris, R. (1997). Peacebuilding and the limits of liberal internationalism. International Security, 22(2), 54-89.

Paris, R. (2004). At war's end. Building peace after civil conflict. Cambridge: Cambridge University Press.

Pawelec, M., \& Grimm, S. (2014). Does national identity matter? EU political conditionality and Serbia's cooperation with the ICTY. Journal of Common Market Studies, 52(6), 1290-1306.

Pearlman, W. (2008). Spoiling inside and out: Internal political contestation and the Middle East peace process. International Security, 33(3), 79-109.

Putnam, R. D. (1988). Diplomacy and domestic politics. The logic of two-level games. International Organization, 42(3), 427-460.

Republic of Croatia. (2007). Pre-accession economic programme. Zagreb.

Republic of Croatia. (2012). Pre-accession economic programme. Zagreb.

Richmond, O. (2010). Resistance and the post-liberal peace. Millennium - Journal of International Studies, 38(3), 665-692.

Richmond, O. (2011). Becoming liberal, unbecoming liberalism: Liberal-local hybridity via the everyday as a response to the paradoxes to liberal peacebuilding. In S. Tadjbaksh (Ed.), Rethinking the liberal peace: External models and local alternatives (pp. 37-56). London: Routledge.

Richmond, O., \& Mitchell, A. (2011). Peacebuilding and critical forms of agency: From resistance to subsistence. Alternatives: Global, Local, Political, 36(4), 326-344.

Richter, S. (2012). Two at one blow? The EU and its quest for security and democracy by political conditionality in the Western Balkans. Democratization, 19(3), 507-534.

Schimmelfennig, F. (2008). EU political accession conditionality after the 2004 enlargement. Consistency and effectiveness. Journal of European Public Policy, 15(6), 918-937.

Schimmelfennig, F., \& Sedelmeier, U. (2004). Governance by conditionality. EU rule transfer to the candidate countries of central and Eastern Europe. Journal of European Public Policy, 11(4), 661679. 
Sedelmeier, U. (2011). Europeanisation in new member and candidate states. Living Reviews in European Governance, 6(1), 5-51.

SIGMA. (2007). Croatia. Public service and the administrative framework. Assessment June 2007. Author. SIGMA. (2008). Croatia. Public service and the administrative framework. Assessment May 2008. Author. Stedman, S. J. (1997). Spoiler problems in peace processes. International Security, 22(2), 5-53.

Streich, P., \& Levy, J. S. (2007). Time horizons, discounting, and intertemporal choice. Journal of Conflict Resolution, 51(2), 199-226.

Walter, S. (2008). A new approach for determining exchange-rate level preferences. International Organization, 62(3), 405-438.

Wolff, J., \& Wurm, I. (2011). Towards a theory of external democracy promotion. Security Dialogue, 42 (1), 77-96.

Zakošek, N. (2008). Democratization, state-building and war: The cases of Serbia and Croatia. Democratization, 15(3), 588-610.

Zürcher, C. (2011). Building democracy while building peace. Journal of Democracy, 22(1), 81-95. 